\title{
The exercise company - alive company
}

\author{
Professor Nicoleta Negoianu \\ Costin C. Kiritescu Economic High School
}

\begin{abstract}
Currently, the need to develop business is complex, from the creation of jobs, to implementing a framework of conduct and action of entrepreneurs on markets in general, the labor market in particular. Romania is a country whose strategic vision must become complementary and compatible with the development trends of the global economy on the one hand, and with internal realities, on the other hand. Given the accelerated growth in unemployment, an insufficient allocation of budgetary resources compared to the development needs of the economy, in this case the business environment to correct economic disparities in relation to the European Union in terms of development of business infrastructure, access to funding sources, the attitude towards the economic environment risk, competition, and a substantial decrease in the tax base caused by the instability of the economic environment and in particular the political, creating new jobs is really a utopia. In this context, entrepreneurship opens new locally development possibilities, where the community builds its own development strategy based on own resources and on identifying needs of community members. A small-scale entrepreneurship development is an example of good practice for other communities without necessarily being implemented on a macroeconomic scale (Bentoiu, Athu, Predonu, 2014). Entrepreneurship policy involves identifying development needs, creating a conceptual framework to support entrepreneurial ideas and their implementation in order to create jobs and sustainable development of the community..
\end{abstract}

Keywords: family Company, the identity of a company, tolerance to novelty, rose garden company

JEL Classification: D10, D11

\section{Introduction}

In the economic field there are always newcomers, new companies. The history of human civilization has shown us that the forms of economic organization are older than 500 years. In early forms of organizing economic activities there has been met the quality of producer of material wealth, enjoying a huge success.

If we look at them in the light of what could have become, most companies have low performances. These happened at a critical early stage of the ladder of evolution, developing and exploiting only a small part of their potential.

In the case of a trait of exacerbated individualism, communities and companies were all affected - even devastated - by premature corporate bankruptcies. Companies went bankrupt because their policies and practices were based too much on economic thinking and language. Companies have died because their 
managers focused exclusively on producing goods and services, forgetting that the organization is a community of human beings involved in business, any business, that must remain active.

Managers themselves are concerned with labor and capital, overlooking the fact that labor means real people. "All happy families resemble one another," wrote Tolstoy in Anna Karenina. But "every unhappy family is unhappy in its own way."

Active companies do have their own personality, allowing them to evolve harmoniously. They know who they are, understand how they fit into the world, evaluate, estimate, appreciate new ideas and new people, manage their money in a way that allows them to govern their future. These personality traits manifest themselves in a behavior intended to renew the company over several generations.

Companies that are active produce goods and services to gain preserving them in the same way in which most of them have jobs in order to live life. As we all know, corporate history consists mainly of selfcongratulatory books and articles written by people from the company itself about the virtues of the Executive Director.

The average lifespan of a company of this kind is much shorter than the life of its potential. Corporations are still in the Stone Age, because they have not realized what potential they have. The average lifespan was expected to less than 20 years. Companies that are active cope very well with the management of change.

\section{Conservatism in financing companies.}

The money from the bank allowed the companies to determine their growth and development. Active companies are able to adapt themselves to changes in the world around them. Wars, political crises and developments in technology have resulted in an increase or a decrease in the capacity to adapt, they always seemed to excel to keep their spiders out, oriented towards whatever have happened. They were able to react in a timely manner to news that they were faced with, they are good at learning lessons from the others and at adaptability. 


\section{Awareness of identity.}

No matter how large and diverse the company is, all employees feel like they are part of a whole. The sense of belonging to an organization and their identification achievements is often dismissed as inconsistent.

\section{Tolerance towards new ideas.}

Longstanding companies tolerated activities in the margin: experiments and eccentricities that stretched their understanding. They recognized that new activities can be entirely irrelevant to existing work and that the act of starting a business requires not to be centrally controlled. W.R. Grace, from the beginnings encouraged autonomous experimentation by definition - a company that has survived more than a century exists in a world that can not hope to control it. Multinationals, such as solid companies must be willing to change in order to succeed.

\section{Valuing people, not assets.}

Goods / assets and profits are like oxygen: necessary for life, but not the purpose of life, assets are only means of livelihood.

Managers should thoroughly assess other people's opinions and practice. The organization must allow people to develop their ideas. They must have some kind of freedom without control, without direction and without punishing failures. Managers must implement the principle of tolerance by taking risks with people and by seeking new places and new ideas. Perhaps the best way to suggest this notion is through the metaphor of

\section{the rose garden.}

Violent cutting means that you've selected the three most powerful strains of a plant and you cut them in three or four buds to determine breeders. This technique forces the plant to channel all resources in a relatively small number of buds. Why did you cut roses in this way? Because you want to have the largest rose among neighbors in June. Others did not practice this method. Why? Because it involves a major risk for the strategy. Long term nipping: the latter would leave 5-6 stems per plant, and 5-6 buds on each stem. As a result the plant would be allowed to scatter resources for more buds. The latter will never have the largest rose compared to neighbors, but they will have roses every June. And so on the long term they will be surprised that the plant will 
grow much stronger, it will produce more buds and stems which no longer will be removed to encourage growth of new ones, using the tolerance method.

This metaphor also helps resolve one of the most modern management dilemmas: how to diversify without creating a mess. A policy of tolerance allows the rose and the environment to engage with one another continuously without disturbing the ability of the rose to grow.

\section{Conclusion}

Concerning the contemporary economies where there is a considerable gap between consumers in terms of income volume, the relation between necessities and possibilities must be adjusted because of social reasons, Engel curve being rather a checked approach over the consumers with low and medium incomes. As for the consumers with low revenues, the parathion optimum is hard to be achieved without a paternalist social component or at least a statist support that encourage public expenses. My opinion is that if the economic agents approached the economic act also from a moral point of view, considering the possibility of getting fortune under the circumstances of competitiveness that should generate jobs on the one hand, and incomes, on the other, the problem of social inequality would be less severe. This way of reasoning may be valid only if the economic interests aim exclusively at the principles of competitive economy: freedom of action for economic agents without conditioning any economic agent.

Also, economic morality can be tackled by judging processes for distributing and redistribution. The process of distribution must be based on the proportionality of each production factor input reflected in the income size and the dynamics of each factor of production. The process of redeployment is exclusively the prerogative of the budgetary policy of the state.

What is bad or immoral within these processes? Firstly, it is the size and the intensity of the interest groups' actions that influence negatively the income volume, as final act of these lawsuits. Regarding the modern economies specific to developing countries, the interest groups which perform their activities using public money will exercise some control on socio-economic and political situations, amplifying social costs, both through economic component and imagistic component of what is being transmitted in economic and political forums at the regional and international level, got through rating of the country or country reports. 


\section{References}

Apostol Diana Mihaela, 2013, Lifestyle şi eco-eficienţă (Lifestyle and Eco-Efficiency), Social Economic Debates, January 2013, Vol. 2, No. 1

Balaceanu Cristina, Barbat Ileana, 2013, Value of economy, Social Economic Debates, January 2013, Vol. 2, No. 1

Bălăceanu Cristina, 2010, Sequential approach of the Romanian economy before and after accession, Universitară Publishing House, Bucharest;

Baumol William J., Litan Robert E., Schramm Carl J., 2009, Good capitalism, bad capitalism and economy development and prosperity, Polirom Publishing House, Bucharest;

Bentoiu Claudia, Athu Cristina, Predonu Andreea-Monica, 2014, Poverty and the Social Exclusion in Compliance with the 2020 EU Strategy, Social Economic Debates, Volume 3, Issue 2, 2014, ISSN 2360-1973, ISSN-L 2248-3837, http://www.economic-debates.ro/2-2014/v3i2a1.pdf; 